\title{
ОСУЩЕСТВЛЕНИЕ КОНТРОЛЬНЫХ ПОЛНОМОЧИЙ ПАРЛАМЕНТОМ РОССИЙСКОЙ ФЕДЕРАЦИИ: ВОПРОСЫ ТЕОРИИ И ПРАКТИКИ
}

\begin{abstract}
Аннотация: В статье рассматривается теория и практика контрольных полномочий парламента, анализируются разнообразные научные взгляды контрольной деятельности парламента, а так же нормативно закрепленные формы парламентского контроля, реализуемые парламентом Российской Федераций. В статье представлено авторское видение нормативно-правового развития контрольных полномочий российского парламента, а так же сделаны предложения по выработке теоретических основ и практических рекомендаций, цель которых направлена на совериенствование конституционного законодательства в исследуемой сфере. В частности дается авторское определение парламентского контроля, цель которого реализовывать принцип «сдержек и противовесов» во взаимоотношениях разных ветвей власти.Основной задачей исследования предполагает обращение к правовому анализу парламентского контроля в Российской Федераџии, а так же анализ реализации практических основ контрольных полномочий парламента. Методическую основу статьи составляет применения диалектического, исторического, системного и сравнительно-правового методов, а так же с использованием системного подхода. В статье подробно анализируется вопросы: правового регулирования парламентского контроля; практическое воплощение и реализация проводимого контроля со стороны Государственной Думы за деятельностью тех или иных субъектов права, в том числе Правительства РФ; формы парламентского контроля; полномочия парламента в данной сфере; научные подходы и взгляды ученых на дальнейшее развитие парламентского контроля в Росси.Автором аргументированы ряд выводов и положений, связанных с дальнейшим совершенствование парламентского контроля, в том числе доказывается, что парламентский контроль является видом государственноправовой деятельности, способствует конструктивному взаимодействию законодательной и исполнительной ветвей власти и сосредоточен на повышении действенности последней.
\end{abstract}

Ключевые слова: Конституцчия, парламентский контроль, Государственная Дума, парламент, полномочия, практика реализачии, ответственность, контроль, запрос, Правительство РФ.

Abstract: This article examines the theory and practice of the Parliament's oversight authority, analyzes various scientific views on the supervision activity of the Parliament, as well as the legal forms of parliamentary oversight exercised by the Parliament of the Russian Federation. The author presents original vision of the legislative development of oversight authority of the Russian Parliament, and offers proposals to devise theoretical basis and practical recommendations aimed at improving the constitutional legislation in this field. The main goal of the research is the legal analysis of the parliamentary oversight in the Russian Federation, as well as analysis of the realization of practical bases of the oversight authority of the Parliament. The article gives a detailed analysis to the following issues: legal regulation of parliamentary supervision; practical implementation and realization of the conducted control by the State Duma over the activity of various subjects of law, including the government of the Russian Federation; forms of parliamentary oversight; authority of the Parliament in this area; scientific approaches and outlooks upon the future development of parliamentary control in Russia. The author substantiates that parliamentary control represents a type of a state legal activity, contributes to the constructive collaboration between legislative and executive branches of the government and is concentrated on increasing the effectiveness of the latter. Keywords: Constitution, Parliamentary supervision, State Duma, Parliament, Authority, Implementation, Responsibility, Control, Inquiry, Russian government.

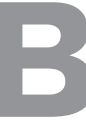

практическом плане вопросам контрольных полномочий парламента России, в Конституции РФ и действующем законодательстве отводится одно из главенствующих мест. Однако, наличие многих юридических коллизий и пробелов в данной области зачастую нивелируют контрольную деятельность парламента и положительный эффект от нее. Поэтому обстоятельное и развернутое изучение не только в практическом, но и теоретическом плане требует разрешения вопросов, как понятийного содержания контрольных полномочий парламента, так и формы реализации данной деятельности, содержания и принципов, целей и функций, классификации и юридического состава эффективного осуществления контрольных полномочий, закрепляемых за парламентом России. 
Научный интерес к вопросам контрольной деятельности парламента возник достаточно давно. Г.Еллинек определял контроль как проверку важных для государства действий его органов и членов с точки зрения соответствия их определенным нормам. Он выделял политический и правовой контроль. Правовой контроль Г.Еллинек делил на административный, финансовый и парламентский. Последний осуществляется посредством критики действий органов правительства при помощи конституционных средств: интерпелляции, резолюции, назначения парламентского следствия. Также Г.Еллинек отмечал, что все виды контроля могут служить как политическим целям, так и целям правового контроля [6, с.10].

Одним из первых исследователей в России, обратившихся к анализу определения института парламентского контроля, был авторский коллектив Энциклопедического словаря по Конституционному праву, который под контрольными полномочиями парламента понимает «вид деятельности, осуществляемый в целях организации выполнения законов и иных нормативных правовых актов, органов государственной власти, соблюдения дисциплины, должного использования финансовых средств и имущества, организации работы с предложениями, заявлениями и жалобами граждан и т.д.» [10, с. 298]. Бесспорно, данное определение является довольно удачной попыткой раскрыть сложное и многогранное определение как парламентский контроль. Однако данное определение не раскрывает основных черт и особенностей парламентского контроля, так как оно относится к 1993 году, когда основы современного российского парламентаризма только формировались, а полномочия парламента, в том числе и контрольные, закреплялись императивно.

По мнению одного из ведущих российских конституционалистов профессора Авакьяна С.А., основной функцией российского парламента является контроль, который относится к одному из видов государственного контроля с целью поддержания устойчивости конституционного строя и реализации принципа сдержек и противовесов. По мнению Авакьяна С.А., парламентский контроль следует относить к самостоятельному институту парламентаризма, цель его связана не только с обеспечением соблюдения и исполнения принятых парламентом законов, представлять и защищать интересы населения всей страны, но и осуществлением контрольной деятельности за исполнительной властью, осуществлять функцию парламентского контроля в области государственного строительства, исполнения бюджета и иной деятельности [1, с. 464-518]
Баглай М.В. определяет парламентский контроль в виде права «представительного органа участвовать в формировании исполнительных органов государственной власти, требовать от них отчета о своей деятельности и отправлять в отставку министров или правительства в целом в случае признания их деятельности неудовлетворительной» [2, с. 318].

Бендюрина С.В. считает, что под парламентским контролем следует понимать разновидность федерального государственного контроля. Парламентский контроль как важнейший институт парламентского права принадлежит к числу исключительных полномочий палат Федерального Собрания Российской Федерации. Федеральный парламентский контроль - это законная деятельность палат Федерального Собрания, их собственных и совместных органов и отдельных представителей, характеризующаяся юридической направленностью по наблюдению, выявлению и предотвращению нарушений, ошибок, злоупотреблений в реализации органами государственной власти, либо должностными лицами нормативных предписаний, и как следствие, возникающим либо не возникающим правовым последствиям [3, с. 8].

По мнению Караева Р.Ш. парламентский контроль - это вид государственно-правовой деятельности законодательного (представительного) органа государственной власти, его уполномоченных на то внутренних структур, парламентариев и специально формируемых им для этой цели государственных органов, включающий комплекс различных легальных мер по постоянному или ситуативному наблюдению, выявлению, вмененной или инициативной проверки органов исполнительной власти в связи с выполнением ими своих задач и функций, а также по корректуре деятельности исполнительной власти с целью предупреждения злоупотреблений и социальных конфликтов, которые могут быть следствием фактов функциональной неэффективности и законодательной неадекватности исполнительной системы [5, с. 11]. Такая трактовка понятия парламентского контроля, по мнению автора статьи, раскрывает сущность и значение данной формы парламентской деятельности. Однако данное определение хоть и является более полным чем у многих авторов, оно менее предпочтительно в силу своей излишней громоздкости.

Таким образом, под парламентским контролем (контрольные полномочия парламента) следует понимать процесс, осуществляемый парламентом по проведению в строго установленных и нормативно закрепленных рамках, проверки с целью определения деятельности 
DOI: $10.7256 / 1811-9018.2015 .11 .16823$

При цитировании этой статьи сноска на dоі обязательна

\section{Право и политика 11 (191) 2015}

органов государственной власти и должностных лиц, в том числе и Правительства РФ, с возможностью применения как неблагоприятных последствий в виде санкций; обязательного принятия решения; выражения политической позиции; так и с целью получения информации, ее переработки и оценки, включающей одобрение или критику органа или должностного лица.

Замечу, что многими исследователями понятие парламентского контроля связывается с деятельность, осуществляемой парламентом страны, входящими и не входящими в его структуру органами и должностными лицами, поэтому выделяются: упреждающий (предварительный), сопутствующий и последующий парламентский контроль; контроль законодательного органа, осуществляемый в определенных сферах деятельности парламента страны [7, с. 25-26]. По данному мнению парламентский контроль сведен к тому, что высший орган законодательной ветви власти - парламента контролирует деятельность органов исполнительной ветви власти [7, с. 19]. Отмечу, что данная позиция не единична, таких же взглядов придерживается и Коврякова Е.В. [6, с. 17].

С данной позицией вышеперечисленных авторов трудно согласиться, так как контрольные полномочия парламента являются довольно обширным, и не сведены только к контролю за органами исполнительной власти. Кроме того, с принятием Федерального закона от 7 мая 2013 г. № 77-Ф3 «О парламентском контроле» [13] (далее - закон о парламентском контроле) парламентарии имеют право в порядке, определенном регламентами палат Федерального Собрания Российской Федерации, осуществлять парламентский контроль в отношении должностных лиц, в том числе заслушивать в целях получения информации по вопросам, носящим чрезвычайный характер, Председателя Правительства РФ, его заместителей, Генерального прокурора РФ, Председателя Центрального банка РФ, Председателя Центральной избирательной комиссии РФ, а так же руководителей иных федеральных государственных органов, государственных внебюджетных фондов Российской Федерации, органов государственной власти субъектов Российской Федерации или органов местного самоуправления по вопросам, входящим в компетенцию указанных органов и должностных лиц.

Рассмотрев вопрос понятия контрольных полномочий парламента России, обращусь к реализации практических основ данных полномочий, которые как было указано выше, содержатся в законе о парламентском контроле. Перед тем как данный закон был принят в 2013 году, он долго не находил поддержки в стенах Правительства РФ. Так в официальном отзыве № 366-ДР от 29 августа 2005 г. на проект федерального закона «О федеральном парламентском контроле» [11], Правительство РФ выразило свое отрицательное отношение, аргументировав свою позицию тем, что нет необходимости и целесообразности дублирования в рассматриваемом законопроекте норм действующего законодательства. В частности, процедуры парламентского и депутатского запросов, парламентских слушаний регулируются Федеральным законом «О статусе члена Совета Федерации и статусе депутата Государственной Думы Федерального Собрания Российской Федерации» и Регламентами Государственной Думы и Совета Федерации. Порядок предоставления ответов на вопросы депутатов Государственной Думы и членов Совета Федерации регулируется членами Правительства Российской Федерации и рядом других должностных лиц, в том числе и Федеральным конституционным законом «О Правительстве Российской Федерации».

Следующая попытка принять закон о парламентском контроле была предпринята парламентариями в 2010 году, но законопроект № 315329-5 «О парламентском контроле в Российской Федерации» также был отклонен Правительством РФ. В своем отзыве на законопроект Правительство РФ пояснило: «в законопроекте отсутствуют четкие критерии, позволяющие определить конкретные случаи осуществления парламентского контроля, а также основания для его осуществления. Кроме того, законопроект во многом дублирует нормы федеральных законов (так, деятельность комиссий палат Федерального Собрания Российской Федерации уже закреплена Федеральным законом «О парламентском расследовании Федерального Собрания Российской Федерации)» [12]. Никак нельзя согласиться с отзывом Правительства РФ, что деятельность палат парламента в вопросах парламентского контроля «фактически будет дублировать деятельность правоохранительных органов», что приведет к нарушению конституционного принципа разделения властей. Такая позиция исполнительной власти не согласуется с конституционным принципом народовластия. Более того, эта позиция «не укладывается в рамки общей тенденции развития российского парламентаризма, характеризующейся повышением роли и значимости законодательных органов власти в жизни общества» [4, с. 62].

Только в 2013 году законопроект № 61834-6 «О парламентском контроле» был принят, причем без получения какого-либо отзыва Правительства РФ.

Целями парламентского контроля являются: обеспечение соблюдения Конституции Российской 
Федерации, исполнения федеральных конституционных законов, федеральных законов; защита гарантированных Конституцией Российской Федерации прав и свобод человека и гражданина; выявление ключевых проблем в деятельности государственных органов Российской Федерации, повышение эффективности системы государственного управления; противодействие коррупции; изучение практики применения законодательства Российской Федерации, выработка рекомендаций, направленных на совершенствование законодательства Российской Федерации и повышение эффективности его исполнения. Производные от целей, в законе закрепляются принципы осуществления парламентского контроля, а также субъекты, которыми стали: комитеты и комиссии двух палат, парламентская комиссия по расследованию фактов и обстоятельств, послуживших основанием для проведения парламентского расследования [16, с.58].

Формы парламентского контроля закрепляются в статье 5 закона о парламентском контроле и всего их 18 . К наиболее значимым и действенным при реализации их на практике возможно отнести: вотум доверия (недоверия) Правительству РФ, инициируемый Государственной Думой; парламентский контроль, как текущий, так и последующий в сфере бюджетных правоотношений; заслушивание Государственной Думой ежегодных отчетов Правительства РФ о результатах его деятельности, в том числе ответов на вопросы, поставленные Государственной Думой; рассмотрение Государственной Думой годовых отчетов Центрального банка Российской Федерации и принятие решений по ним; парламентские запросы в Правительство РФ; проведение парламентских расследований; назначение на должность и освобождение от должности Председателя Счетной палаты Российской Федерации, его заместителя и аудиторов; заслушивание Советом Федерации ежегодных докладов Генерального прокурора Российской Федерации о состоянии законности и правопорядка в Российской Федерации и о проделанной работе по их укреплению; осуществление Государственной Думой взаимодействия с Уполномоченным по правам человека в Российской Федерации; проведение парламентских слушаний; проведение парламентских расследований.

Все формы парламентского контроля возможно разграничить на три большие группы. К первой группе относятся контрольные полномочия парламента за деятельностью Правительства РФ и его членов, т.е. контрольные полномочия парламента за исполнительной властью. Причем реализация данных видов контрольных полномочий закрепляется за
Государственной Думой. Ко второй группе относятся полномочия по контролю за иными органами государственной власти и должностными лицами, в основном такие полномочия не могут негативно отразиться на контролируемых субъектах, а связаны с информированием в той или иной области их деятельности палат парламента со стороны подконтрольных субъектов. В третью группу контрольных полномочий не включен конкретный субъект контроля, такие полномочия возможно назвать «внешними» и «неограниченными по субъектному составу».

Не буду останавливаться на каждом отдельном полномочии, тем более глава 2 закона о контрольных полномочиях посвящена отдельным ее формам, а заострю внимание на вопросах эффективности реализации контрольных полномочий парламента и связанных с этим проблемах. Замечу, что в настоящий момент на передний план выходит необходимость осознания того, что эффективность воздействия со стороны парламента невозможна без ясного и глубокого понимания им своей ответственности в данных правоотношениях. Данный вопрос, при его очевидной малоизученности, является весьма актуальным и значимым как для теории парламентского контроля, так и для практики взаимодействия парламента и иных органов государственной власти.

Наиболее эффективными и вместе с тем проблемными формами парламентского контроля по моему мнению можно считать следующие:

1. Направление членами Совета Федерации, депутатами Государственной Думы запросов членов Совета Федерации, запросов депутатов Государственной Думы (далее - депутатский запрос);

Депутатский запрос. Самогоопределения данного института в законодательстве не закреплено, однако из содержания Регламентов Государственной Думы, Совета Федерации, Правительства РФ, а также закона о парламентском контроле можно сделать вывод, что депутатский запрос - это устное или письменное обращение к любым органам и должностным лицам (за исключением Президента РФ) в Российской Федерации с требованиями или предложениями предоставить информацию, совершить определенное действие, отчитаться по вопросу, который находится в компетенции органа или должностного лица.

Между депутатским запросом и парламентским запросом часто ставят знак равенства, однако это в корне не верно. Отличие этих двух форм парламентского контроля заключается в субъектном составе. Однако отметим, что после принятия закона о парламент- 
DOI: $10.7256 / 1811-9018.2015 .11 .16823$

При цитировании этой статьи сноска на dоі обязательна

\section{Право и политика $11(191) \cdot 2015$}

ском контроле эти две формы (депутатский запрос и парламентский запрос) согласно статье 8 указанного закона стали отождествляться: «Парламентский запрос, депутатский запрос». Так, палаты Федерального Собрания РФ, согласно своим регламентам, направляют парламентский запрос, а члены Совета Федерации, депутаты Государственной Думы - депутатский запрос. Должностное лицо, которому направлен парламентский запрос, должно дать на него ответ в устной или в письменной форме не позднее чем через пятнадцать дней со дня получения парламентского запроса. Палата Федерального Собрания Российской Федерации в случае, если ответ на парламентский запрос признан неудовлетворительным, вправе принять решение о повторном направлении парламентского запроса.

Согласно статистике депутатского запроса как формы парламентского контроля, инициируемого депутатами Госдумы, которых, начиная с 1997 года было не менее 2000 ежегодно, а в определенные годы - 1999, 2004, переваливало далеко за 3000. Следует подчеркнуть, депутатский запрос «не воспринимается как проявления контрольной функции парламента, ни самим законодателем, ни ведомственным нормотворцем. Для последнего - что собственно запрос депутата, что его личная просьба, что требование информации практически одно и то же. Запросы по своим правовым последствиям мало чем отличаются даже от обычных обращений граждан» [8, с.31].

Переломить данную ситуацию, возможно только через логично построенную систему контроля, которая будет четко закреплена не в регламентах (внутреннем, локальном акте), а в законе, хотя бы в том же самом - о парламентском контроле. Во-первых, парламенту страны требуется без оглядки на конъюнктурные соображения, лоббистские искушения и иные препятствия, внести изменения в законодательство, четко разделив парламентский запрос и депутатский запрос. Во-вторых, четко обозначить содержание и регламент этих двух форм контроля, а также субъектный состав. Представляется абсолютно бессмысленным дублировать субъектов парламентского и депутатского запроса.

2 . Правительственный час - представляющий собой заслушивание на заседаниях палат информации членов Правительства Российской Федерации, руководителей и должностных лиц федеральных органов исполнительной власти, ответов указанных должностных лиц на вопросы членов Совета Федерации, депутатов Государственной Думы в рамках «правительственного часа», а также заслушивание информации указанных должностных лиц на заседаниях комитетов и комиссий палат Федерального Собрания Российской Федерации. Проведение «правительственного часа» как форма парламентского контроля является более разработанной и систематизированной процедурой по отношению к ранее рассмотренной форме - депутатскому (парламентскому) запросу. Сама подготовка «правительственного часа» прописывается довольно основательно в Регламенте Совета Федерации, в котором данной форме контроля посвящена целая глава 8 «Порядок подготовки и проведения «правительственного часа» на заседании Совета Федерации». Напротив же, в Регламенте Государственной Думы данные вопросы рассматриваются крайне поверхностно и регламентируются только статьей 41.

Под «правительственным часом» понимается время, отведенное на заседании парламента верхней или нижней палаты, для ответов председателя Правительства, его заместителей и рядовых членов, а также других должностных лиц, на вопросы депутатов. Форма такого парламентского контроля подразумевает регулярность проведения. Периодичность проведения зависит от решения палаты. Так, согласно статьи 41 Регламента, «Правительственный час» проводится каждую среду на заседании Государственной Думы. Также предусматривается возможность назначения и внепланового «правительственного часа» или отмены его вовсе. В рамках заседания заслушиваются не более двух приглашенных членов Правительства Российской Федерации.

Поэтому контрольные полномочия парламента в рамках «правительственного часа» не должны сводиться к ответам федерального министра или иного должностного лица на вопросы депутатов. Для того, чтобы хотя бы попытаться практически реализовать контрольные полномочия, необходимо их систематизировать. А так же прописать, какие решения должны быть принимаемы в рамках данной формы парламентского контроля, как данные решения должны быть реализованы, какая ответственность наступает за их неисполнение, кто потенциально несет данную ответственность. Все эти и многие другие методы и средства решения имеющейся проблемы должны стать правовой основой, образно выражаясь фундаментом, на котором и будет строиться зарождающийся парламентский контроль.

3. Заслушивание в целях получения информации по вопросам, носящим чрезвычайный характер Председателя Правительства РФ, его заместителей, иных должностных лиц.

Новеллой формы взаимодействия парламента и правительства стала именно информационная составляющая в рамках вопросов, носящих чрезвычайный 
DOI: 10.7256/1811-9018.2015.11.16823

При цитировании этой статьи сноска на dоі обязательна

Власть и управление

характер. В этой связи сложно данную форму назвать механизмом воздействия парламента на правительство, а следует вести речь о некой справочной или уведомительной функции, исполняемой Правительством РФ с целью информационного наполнения парламентских сессий.

Помимо закона о парламентском контроле, закрепление в законодательстве информационной формы в виде заслушивания в целях получения информации по вопросам, носящим чрезвычайный характер, получило в Федеральный конституционный закон от 07.05.2013 г. №2-ФКЗ «О внесении изменений в Федеральный конституционный закон «О Правительстве Российской Федерации» [14]. Согласно п. 3.1. ст. 38 Регламента Государственной Думы, приглашенными могут быть Премьер-министр, его заместители, а также Генпрокурор, Председатель Центробанка, Председатель Центризбиркома, иные должностные лица. Приглашение осуществляется Государственной Думой, а предложения инициируют сами депутаты, а так же фракции, комитеты и комиссии в Государственной Думе. Вопросы, обусловившие данное приглашение могут быть заданы «в целях получения информации по вопросам, носящим чрезвычайный характер».

Развитие данной формы имеет место в статье 12 закона о парламентском контроле, где закрепляется участие в работе правительственной комиссии по расследованию причин возникновения обстоятельств чрезвычайного характера и ликвидации их последствий, представителей палат Федерального Собрания РФ. Они могут (обращаю внимание - могут) привлекаться к работе в правительственной комиссии по расследованию причин возникновения обстоятельств чрезвычайного характера и ликвидации их последствий по решению Правительства Российской Федерации. Таким образом, если Правительство позволит членам парламента поучаствовать в работе своей комиссии, то они поучаствуют, если не позволит, то им только и останется что задавать вопросы согласно своим регламентам.

Таким образом, практика применения данной формы парламентского контроля в России пока еще не сложилась. Какие вопросы носят чрезвычайный характер правоприменителю тоже неизвестно. Однако можно предположить, что ими могут являться закрепленные в статье 3 Федерального конституционного закона от 30.05.2001 № 3-ФКЗ (ред. от 07.03.2005) «О чрезвычайном положении» [15], обстоятельства введения чрезвычайного положения, которое вводится при наличии обстоятельств, представляющих собой непосредственную угрозу жизни и безопасности граждан или конституционному строю России.
4. Проведение парламентских слушаний. Нормативной основой для проведения обеими палатами федерального собрания парламентских слушаний является часть 3 статьи 101 Конституции РФ, согласно которой «Совет Федерации и Государственная Дума образуют комитеты и комиссии, проводят по вопросам своего ведения парламентские слушания». Проведение парламентских слушаний, их осуществление и организация четко закреплены в регламентах палат. Отмечу, что общим вопросам парламентских слушаний в России и зарубежных странах уделялось и уделяется внимание во многих научных работах [9], поэтому не буду подробно останавливаться на этом.

Парламентские слушания всегда связаны с обсуждением той или иной чрезвычайно важной проблемы и производятся с привлечением широкого круга субъектов (общественных объединений, специалистов в той или иной области, должностных лиц и т.д.).

Парламентские слушания проводятся Государственной Думой по инициативе Совета Государственной Думы, комитетов и комиссий Государственной Думы, фракций. А в Совете Федерации слушания проводятся по инициативе Председателя Совета Федерации, Совета палаты, комитета Совета Федерации по вопросам его ведения или группы членов Совета Федерации численностью не менее 15 человек. Также не исключена возможность проведения парламентских слушаний совместно с комитетами и комиссиями Государственной Думы, парламентами (палатами парламентов) иностранных государств.

Представляет интерес положение п. 5 ст. 89 регламента Совета Федерации, провозглашающее, что лица (в том числе и члены Правительства РФ) могут не отвечать на вопросы членов Совета Федерации, если они касаются сведений, составляющих государственную или иную охраняемую законом тайну. Документами, подводящим итог парламентским слушаниям могут являться рекомендации или руководства к действию для Правительства РФ. Указанные документы утверждаются комитетом палаты, ответственным за подготовку проведения парламентских слушаний, либо Советом палаты, либо Советом Федерации (ч. 1 ст. 90 Регламента Совета Федерации). В Государственной Думе парламентские слушания также могут заканчиваться принятием рекомендаций по обсуждаемому вопросу. Рекомендации как итог парламентских слушаний принимаются путем одобрения большинством принявших участие в парламентских слушаниях депутатов Государственной Думы (ст. 70 Регламента Государственной Думы). 
DOI: $10.7256 / 1811-9018.2015 .11 .16823$

При цитировании этой статьи сноска на dоі обязательна

\section{Право и политика $11(191) \cdot 2015$}

Таким образом, в законодательстве не содержится нормативного закрепления понятия парламентских слушаний, однако можно обратиться к научным подходам в определении сущности парламентских слушаний, применительно к системе парламентского контроля деятельности Правительства РФ.

Довольно активным исследователем контрольных полномочий парламента является Бендюрина С.В., которая обуславливает общую систему парламентского контроля: 1. общественной значимостью рассматриваемых на парламентских слушаниях вопросов; 2 . масштабностью тех вопросов, которые подлежат обсуждению на парламентских слушаниях; 3. Парламентские слушания способствуют осуществлению взаимоконтроля со стороны законодательной, исполнительной, и даже судебной ветвей власти, что обеспечивает тем самым определенный баланс интересов; 4. привлечением внимания разного рода представителей, как со стороны государства и его органов, так и гражданского общества. Это внимание подразумевает тесное сотрудничество всех органов государственной власти и сопровождается в дальнейшем выработкой рекомендаций, либо принятием решений [3, с. 16]. Однако, совершенно верно обращает внимание Бендюрина С.В. на столь очевидный недостаток парламентских слушаний, проявляющийся в том, что решения палат парламента носят рекомендательный характер и никого ни к чему не обязывают.

Таким образом, на сегодняшний день, парламентские слушания действительно стали активно используемой формой парламентского контроля, подтверждением чему являются статистические данные, показывающие, что за 2012 год Совет Федерации провел около 25 парламентских слушаний, в которых большая часть вопросов относилась к финансово бюджетной сфере, т.е. непосредственно к прямому назначению деятельности Правительства РФ. В 2013 году парламентские слушания были проведе- ны почти 30 раз, в половине случаев с приглашением членов Правительства РФ. Однако до тех пор, пока решения, выработанные в процессе парламентских слушаний будут носить сугубо рекомендательный характер, парламентские слушания никогда не станут эффективной формой парламентского контроля, тем более за исполнительной властью.

Подводя итог отмечу, что для развития контрольных полномочий парламента необходимо не просто прописать законодательно, а на деле создать действенную систему функционирования парламентского запроса, правительственного часа и парламентских слушаний. Перспективу я вижу, в том, что с помощью упомянутых контрольных форм можно было бы осуществлять эффективные решения. Необходимо из огромного набора (18 разнообразных форм парламентского контроля) выбрать наиболее действенные для результативного функционирования системы парламентского контроля во взаимодействии с органами исполнительной власти и должностными лицами.

Так считаю, что парламентский контроль - важнейший и неотъемлемый элемент демократического правового государства. Цель его - реализовывать принцип «сдержек и противовесов» во взаимоотношениях разных ветвей властей. Поэтому, по моему мнению, реализация парламентского контроля предполагает выработку собственной специфической модели с учетом ориентации на активную позицию лиц, представляющих гражданское общество в законодательном органе государственной власти, характеризует состояние и степень подлинной заинтересованности этого общества в совершенствовании государственного управления; в-третьих, парламентский контроль является видом государственно-правовой деятельности, способствует конструктивному взаимодействию законодательной и исполнительной ветвей власти и сосредоточен на повышении действенности последней.

\section{Библиография:}

1. Авакьян С.А. Федеральное Собрание-парламент России. М., 1999. С. 405-406. Его же. Конституционное право России. Учебный курс: учеб.пособие: в 2 т. 4-е изд., перераб. и доп. Т.

2. М.: Норма, 2014. С. 464-518. 2.Баглай, М. В. Малая энциклопедия конституционного права / Баглай, Марат Викторович, В. А. Туманов. - М. : БЕК, 1998. - С. 318.

3. Бендюрина С.В. Федеральный парламентский контроль в Российской Федерации: Автореф. дисс. ... канд. юрид. наук. Екатеринбург, 2003. С. 16.

4. Демидов М.В. Парламентский финансовый контроль в России: правовые аспекты функционирования и проблемы реализации:Дисс. ... д-ра.юрид. наук. М. 2011. - С. 62.

5. Караев Р.Ш. Конституционно-правовые формы парламентского контроля за исполнительной властью в Российской Федерации :Дис. .... канд. юрид. наук С. 11.

6. Коврякова Е.В. - Парламентский контроль: зарубежный опыт и российская практика. М.: ОАО «Издательский дом «Гододец»» $-2005-10 \mathrm{c}$. 
DOI: $10.7256 / 1811-9018.2015 .11 .16823$

При цитировании этой статьи сноска на doi обязательна

Власть и управление

7. Корнилаева А.А. Теория парламентского контроля в контексте принципа разделения властей: Автореф. дисс. ... канд. юрид. наук. Уфа, 2002. С. 25-26.

8. Краснов М.А Способен ли депутатский запрос быть средством парламентского контроля? Краснов М.А. ГУ ВШЭ. ...Статья Автор. Издательство: ГУ ВШЭ Место издания: Москва Количество страниц: 16-32 Год издания: 2009 г. С. 31.

9. Никитенко М.Г. Депутатские (парламентские) слушания в Российской Федерации: дис. ... канд. юрид. наук Хабаровск, 2006.; Игнатов Е.А. Парламентские процедуры в Государственной Думе Федерального Собрания Российской Федерации (Конституционно-правовой аспект): Дис. ... канд. юрид. наук: М., 2003.; Конституционное (государственное) право зарубежных стран: Учебник под ред. А.С. Автономова. М. 2001 г.;

10. Ожегов СИ., Шведова Н.Ю. Толковый словарь русского языка: 72500 слов и 7500 фразеологических выражений / Российская академия наук, Институт русского языка, Российский фонд культуры. М.: Азъ, 1993. С. 298.

11. Официальный сайт Государственной Думы Федерального Собрания Российской Федерации. http://asozd2.duma.gov.ru/ arhiv/a_dz_4.nsf/ByID/0F92990C73005941432571BB005886F7?Open

12. Официальный сайт Государственной Думы Федерального Собрания Российской Федерации. http://asozd2.duma.gov.ru/ main.nsf/(SpravkaNew)?OpenAgent\&RN=315329-5\&02

13. Федерального закона от 7 мая 2013 г. № 77-ФЗ «О парламентском контроле» // СЗ РФ. 13.05.2013. № 19, ст. 2304.

14. Федеральный конституционный закон от 07.05.2013 N 2-ФКЗ «О внесении изменений в Федеральный конституционный закон «О Правительстве Российской Федерации» // Собрание законодательства РФ, 13.05.2013, № 19, Ст. 2293

15. Федеральный конституционный закон от 30.05.2001 № 3-ФКЗ (ред. от 07.03.2005) «О чрезвычайном положении»// Собрание законодательства РФ, 04.06.2001, № 23, ст. 2277.

16. Чепус А.В. Эффективность механизма парламентского контроля в России. / А.В. Чепус // Государственная служба. 2014. - № 3. - С. 58

17. Чепус А.В. Правительство Российской Федерации: состав и порядок его формирования // Политика и Общество. - 2015. - 2. - C. 230 - 240. DOI: 10.7256/1812-8696.2015.2.14459.

18. Кравец И.А. О понимании и судьбе монархического бикамерализма в России в начале ХХ века // Политика и Общество. - 2014. - 9. - С. 1082 - 1094. DOI: 10.7256/1812-8696.2014.9.13057.

19. А. Д. Керимов, Е. В. Халипова Правомерно ли выделение лишь трёх ветвей государственной власти? // Политика и Общество. - 2012. - 3. - С. $42-48$.

\section{References (transliterated):}

1. Avak'yan S.A. Federal'noe Sobranie-parlament Rossii. M., 1999. S. 405-406. Ego zhe. Konstitutsionnoe pravo Rossii. Uchebnyi kurs: ucheb.posobie: v 2 t. 4-e izd., pererab. i dop. T.

2. M.: Norma, 2014. S. 464-518. 2.Baglai, M. V. Malaya entsiklopediya konstitutsionnogo prava / Baglai, Marat Viktorovich, V. A. Tumanov. - M. : BEK, 1998. - S. 318

3. Bendyurina S.V. Federal'nyi parlamentskii kontrol' v Rossiiskoi Federatsii: Avtoref. diss. ... kand. yurid. nauk. Ekaterinburg, 2003. S. 16.

4. Demidov M.V. Parlamentskii finansovyi kontrol' v Rossii: pravovye aspekty funktsionirovaniya i problemy realizatsii:Diss. ... d-ra.yurid. nauk. M. 2011. - S. 62.

5. Karaev R.Sh. Konstitutsionno-pravovye formy parlamentskogo kontrolya za ispolnitel'noi vlast'yu v Rossiiskoi Federatsii :Dis. ... kand. yurid. nauk S. 11.

6. Kovryakova E.V. - Parlamentskii kontrol': zarubezhnyi opyt i rossiiskaya praktika. M.: OAO «Izdatel'skii dom «Gododets»»»-2005 - 10 s.

7. Kornilaeva A.A. Teoriya parlamentskogo kontrolya v kontekste printsipa razdeleniya vlastei: Avtoref. diss. ... kand. yurid. nauk. Ufa, 2002. S. 25-26.

8. Krasnov M.A Sposoben li deputatskii zapros byt' sredstvom parlamentskogo kontrolya? Krasnov M.A. GU VShE. ...Stat'ya Avtor. Izdatel'stvo: GU VShE Mesto izdaniya: Moskva Kolichestvo stranits: 16-32 God izdaniya: 2009 g. S. 31.

9. Nikitenko M.G. Deputatskie (parlamentskie) slushaniya v Rossiiskoi Federatsii: dis. ... kand. yurid. nauk Khabarovsk, 2006.; Ignatov E.A. Parlamentskie protsedury v Gosudarstvennoi Dume Federal'nogo Sobraniya Rossiiskoi Federatsii (Konstitutsionnopravovoi aspekt): Dis. ... kand. yurid. nauk: M., 2003.; Konstitutsionnoe (gosudarstvennoe) pravo zarubezhnykh stran: Uchebnik pod red. A.S. Avtonomova. M. 2001 g.;

10. Ozhegov SI., Shvedova N.Yu. Tolkovyi slovar' russkogo yazyka: 72500 slov i 7500 frazeologicheskikh vyrazhenii / Rossiiskaya akademiya nauk, Institut russkogo yazyka, Rossiiskii fond kul’tury. M.: Az”, 1993. S. 298.

11. Chepus A.V. Effektivnost' mekhanizma parlamentskogo kontrolya v Rossii. / A.V. Chepus // Gosudarstvennaya sluzhba. - 2014. - № 3. - S. 58

12. Chepus A.V. Pravitel'stvo Rossiiskoi Federatsii: sostav i poryadok ego formirovaniya // Politika i Obshchestvo. - 2015. - 2. - C. 230 - 240. DOI: 10.7256/1812-8696.2015.2.14459.

13. Kravets I.A. O ponimanii i sud'be monarkhicheskogo bikameralizma v Rossii v nachale XX veka // Politika i Obshchestvo. 2014. - 9. - C. 1082 - 1094. DOI: 10.7256/1812-8696.2014.9.13057.

14. A. D. Kerimov, E. V. Khalipova Pravomerno li vydelenie lish' trekh vetvei gosudarstvennoi vlasti? // Politika i Obshchestvo. 2012. - 3. - C. $42-48$. 